\title{
Family physician views about primary care reform in Ontario: a postal questionnaire Duncan JW Hunter* ${ }^{* 1,2,3}$, Samuel ED Shortt ${ }^{\dagger 1,2,3,4}$, Peter M Walker ${ }^{\dagger 5}$ and Marshall Godwin ${ }^{\dagger 2,3,4}$
}

\begin{abstract}
Address: ${ }^{1}$ Centre for Health Services and Policy Research, Queen's University, Kingston, Ontario, Canada, ${ }^{2}$ Centre for Studies in Primary Care, Queens University, Kingston, Ontario, Canada, ${ }^{3}$ Department of Community Health \& Epidemiology, Queen's University, Kingston, Ontario, Canada, ${ }^{4}$ Department of Family Medicine, Queen's University, Kingston, Ontario, Canada and ${ }^{5}$ School of Medicine, Queen's University, Kingston, Ontario, Canada

Email: Duncan JW Hunter* - hunter@post.queensu.ca; Samuel ED Shortt - seds@post.queensu.ca; Peter M Walker - pmw2@qlink.queensu.ca; Marshall Godwin - godwinm@post.queensu.ca

* Corresponding author †Equal contributors
\end{abstract}

Published: 01 March 2004

BMC Family Practice 2004, 5:2

This article is available from: http://www.biomedcentral.com/I47I-2296/5/2

(C) 2004 Hunter et al; licensee BioMed Central Ltd. This is an Open Access article: verbatim copying and redistribution of this article are permitted in all media for any purpose, provided this notice is preserved along with the article's original URL.
Received: 12 September 2003

Accepted: 0I March 2004

\begin{abstract}
Background: Primary care reform initiatives in Ontario are proceeding with little information about the views of practicing family physicians.

Methods: A postal questionnaire was sent to 1200 randomly selected family physicians in Ontario five months after the initial invitation to join the Ontario Family Health Network. It sought information about their practice characteristics, their intention to participate in the Network and their views about the organization and financing of primary care.

Results: The response rate was $\mathbf{5 0 . 3 \%}$. While many family physicians recognize the need for change in the delivery of primary care, the majority (72\%) did not expect to join the Ontario Family Health Network by 2004 , or by some later date (60\%). Nor did they favour capitation or rostering, 2 key elements of the proposed reforms. Physicians who favour capitation were 5.5 times more likely to report that they expected to join the Network by 2004 , although these practices comprise $5 \%$ of the sample.
\end{abstract}

Conclusions: The results of this survey, conducted five months after the initial offering of primary care reform agreements to all Ontario physicians, suggest that an $80 \%$ enrollment target is unrealistic.

\section{Background}

Since the inception of Canadian medicare in the late 1960 s there have been recurrent cycles, albeit largely fruitless, of demands for innovation to primary care delivery models [1]. Increasingly, however, the need to review and revise the delivery of primary care has assumed new urgency and is currently seen as a core health policy issue in the developed world and beyond [2]. Primary care reform has been advocated by provincial and national commissions in Canada as fundamental to health system restructuring [3-6]. In Ontario, two main models of reformed primary care (reformed fee-for-service and global capitation) have been initiated as pilot projects and evaluated[7]. In 2001 the Ontario government launched the Ontario Family Health Care Network, intended to enlist $80 \%$ of practitioners by the year 2004 into a 
redesigned model of delivering primary care. The key elements in this model include: patient rostering, capitation payment with added incentives for prevention and other targeted services, provision of out-of-hours service and tele-triage, and extensive use of electronic medical records and linkages[8].

The move towards changes in the delivery of primary care appears to be a top-down process driven by provincial Ministries of Health. What do 'grass-roots' practitioners feel about change? A study in 2001 found that only five percent of Ontario family physicians, in practice eight to ten years, believed primary care reform would have a favourable effect on their practices[9]. A subsequent study of physicians who were eligible for, but did not participate in, a primary care reform pilot project identified many concerns about the impact of a new system on: practice routines, working conditions, financial arrangements and loss of autonomy[10].

Currently in Ontario the long-standing Community Health Centre and Health Services Organization programs, and recent primary reform sites, account for only about five percent of family physician practices[1]. This small number, along with evidence that practitioners are sceptical about current reforms, suggests that the recruitment target may be unrealistic. The aims of this study are: 1) to determine whether family physicians intended to participate in the Ontario Family Health Care Network; and 2) to identify factors that may influence their decision.

\section{Methods}

A cross-sectional survey of family physicians in Ontario was carried out in July 2002. A two page questionnaire, along with a covering letter and a pre-paid return envelope, was sent to 1200 family physicians, randomly selected from a list of 5200 members of the Ontario College of Family Physicians. The college represents 65\% of all practicing family physicians in the province of Ontario. Non-responders were sent a second questionnaire one month later. The questionnaire sought information about physicians (age, sex, years in practice), practice characteristics (type, size, remuneration, percent of time spent in clinical practice, use of computer, out-of-hours service) and their level of agreement with several statements related to primary care reform in Ontario (Table 1). The level of agreement ranged from: strongly agree, agree, slightly agree, slightly disagree, disagree, to strongly disagree. The wording of statements is presented in Table 1 . To test for sampling bias, responder characteristics (age, sex, years in practice) were compared with the Ontario responses to the 2001 National Family Physician Workforce Survey [11].

Data analysis consisted of frequency distributions and the calculation of odds ratios. The variables were re-coded as follows: age-group [less than 44 vs. $45+$ years], years in practice [less than 9 years vs. 10 years or greater], type of practice [solo vs. group, community health centre, health services organization, other], remuneration [fee-for-service vs. capitation, salary, other], size of practice [less than 1500 vs. 1500 or more patients], percent time in clinical practice and [less than $75 \%$ vs. greater than $75 \%$ ]. Level of agreement was re-coded as either agreement [strongly agree, agree, slightly agree] or disagreement [slightly disagree, disagree, strongly disagree].

All analyses were conducted using procedures written in SAS[12]. Ethics approval was received from the Queen's University Health Sciences and Affiliated Teaching Hospitals Research Ethics Board.

\section{Results}

Of the 1200 family physicians sent a questionnaire, 50 were not in practice so the final study population was 1150. 565 questionnaires were not returned and a further 8 were returned without a response so that the final response rate was $50.2 \%$ (577/1150). The mean age of responders was 44 years, with the majority of responders (39\%) aged between 35-44 years (Table 2). There were

\section{Table I: Statements used to elicit family physician views about primary care reform in Ontario.}

\footnotetext{
I understand the Ontario Family Health Network well enough to make informed decisions about my involvement

I expect to be part of the Ontario Family Health Network by 2004

I expect to be part of the Ontario Family Health Network at some time after 2004

The current system for the organization of primary care delivery in Ontario needs to be changed

The current system for the financing of primary care delivery in Ontario needs to be changed

A capitation based formula for funding physician services would improve primary care in Ontario

A roster that links a patient to a single care provider would improve primary care in Ontario

Appropriate financial incentives would enhance preventive interventions in primary care

Patients should always have access to extended weeknight and weekend office hours

A telephone health line staffed by a qualified nurse is a good resource to direct patients to appropriate care

I would like to see computer systems replace most of the paper systems in my practice
} 
Table 2: Characteristics of respondents and their practices, family physicians in Ontario, 2002.

\begin{tabular}{|c|c|c|c|}
\hline Characteristic & & $\mathbf{N}$ & (\%) \\
\hline \multicolumn{4}{|c|}{ Age group (missing = 66) } \\
\hline & $25-34$ years & 101 & 19.8 \\
\hline & $35-44$ years & 198 & 38.8 \\
\hline & $45-54$ years & 155 & 30.3 \\
\hline & $55-64$ years & 57 & 11.2 \\
\hline \multicolumn{4}{|l|}{ Sex } \\
\hline & Females & 259 & 44.9 \\
\hline & Males & 318 & 55.1 \\
\hline \multicolumn{4}{|c|}{ Years in practice $($ missing $=90)$} \\
\hline & $0-9$ years & 186 & 38.2 \\
\hline & $10-19$ years & 168 & 34.5 \\
\hline & $20-29$ years & 107 & 22 \\
\hline & $30-39$ years & 26 & 5.3 \\
\hline \multicolumn{4}{|c|}{ Practice tyype (missing $=4)$} \\
\hline & Solo & 169 & 29.5 \\
\hline & Group & 318 & 55.5 \\
\hline & Community Health Centre & 27 & 4.7 \\
\hline & Health Services Organization & 18 & 3.1 \\
\hline & Other & 41 & 7.2 \\
\hline \multicolumn{4}{|c|}{ Primary Clinical Income (missing $=4$ ) } \\
\hline & Fee for service & 464 & 81 \\
\hline & Capitation & 29 & 5.1 \\
\hline & Salary & 58 & 10.1 \\
\hline & Other & 22 & 3.8 \\
\hline \multicolumn{4}{|c|}{ Size of practice $($ missing $=25$ ) } \\
\hline & $<500$ patients & 21 & 3.8 \\
\hline & $500-1000$ patients & 61 & II.I \\
\hline & $1001-1500$ patients & 116 & 21 \\
\hline & $|50|-2000$ patients & 144 & 26.1 \\
\hline & $200 \mathrm{I}-2500$ patients & 90 & 16.3 \\
\hline & $>2500$ patients & 120 & 21.7 \\
\hline \multicolumn{4}{|c|}{ Percent time in clinical practice (missing $=2$ ) } \\
\hline & $<25 \%$ & 12 & 2.1 \\
\hline & $25-50 \%$ & 29 & 5.1 \\
\hline & $51-75 \%$ & 103 & 17.9 \\
\hline & $76-100 \%$ & 431 & 75 \\
\hline \multicolumn{4}{|c|}{ Use computer (missing $=12$ ) } \\
\hline & Billing only & 169 & 29.9 \\
\hline & Billing, scheduling \& registration & 337 & 59.5 \\
\hline & Full electronic record & 59 & 10.4 \\
\hline \multicolumn{4}{|c|}{ Out of hours service* } \\
\hline & Use on-call physician & 357 & 61.9 \\
\hline & Sign-out to emergency & 180 & 31.2 \\
\hline & Sign-out to walk-in clinic & 154 & 26.7 \\
\hline & Week-day evening hours & 155 & 26.9 \\
\hline & Week-end evening hours & 84 & 14.6 \\
\hline
\end{tabular}

\footnotetext{
* More than one response allowed, so numbers don't add up to 577.
}

slightly more men (55\%) than women (45\%). Responders had practiced for an average of 15 years, with $38 \%$ of family physicians reporting that they had practiced for less than 9 years. Most practices differed from the type proposed by the Network (72\%). Table 3 shows a comparison of sample characteristics with those of the Ontario portion of the National Family Physician Workforce Sur- vey. Responders to the present survey were more likely to be younger, to be women and to have practiced for less time than the Ontario responders to the national survey.

The frequency distribution of practice characteristics is presented in Table 2 . The majority of family physicians $(56 \%)$ worked in group practices, while the remainder 
Table 3: Comparison of responders characteristics with the Ontario component of the National Family Physician Workforce Survey, 2001.

\begin{tabular}{|c|c|c|c|c|c|}
\hline Characteristic & & $\mathbf{N}$ & (\%) & $\mathbf{N}$ & (\%) \\
\hline \multicolumn{6}{|l|}{ Age } \\
\hline & $25-34$ years & 101 & 19.8 & 760 & 8.7 \\
\hline & $35-44$ years & 198 & 38.8 & 2629 & 29.7 \\
\hline & $45-54$ years & 155 & 30.3 & 2958 & 33.5 \\
\hline & $55-64$ years & 57 & 11.2 & 1606 & 18.4 \\
\hline & $65+$ & -- & -- & 781 & 8.9 \\
\hline & Missing & 66 & & 214 & \\
\hline \multicolumn{6}{|l|}{ Sex } \\
\hline & Females & 259 & 44.9 & 2778 & 31.8 \\
\hline & Males & 318 & 55.1 & 5951 & 68.2 \\
\hline & Missing & 0 & & 112 & \\
\hline \multicolumn{6}{|c|}{ Years in practice } \\
\hline & $0-9$ years & 186 & 38.2 & 1699 & 19.4 \\
\hline & $10-19$ years & 168 & 34.5 & 2827 & 32.3 \\
\hline & $20-29$ years & 107 & 22 & 2424 & 27.7 \\
\hline & $30-39$ years & 26 & 5.3 & 1297 & 14.8 \\
\hline & $40+$ years & -- & & 497 & 5.7 \\
\hline & Missing & 90 & & 98 & \\
\hline
\end{tabular}

worked in solo practices (30\%), 'other' practices $(7 \%)$, community health centres (5\%), or health services organizations (3\%). A substantial majority (81\%) reported that they were remunerated on a fee-for-service basis - of the remainder, $10 \%$ were salaried, $5 \%$ were paid on a capitation basis and 4\% were 'other'. Practice sizes were: less than 500 patients (4\%); 500-1000 patients (11\%), 10011500 patients (21\%), 1501-2000 patients (26\%), 20012500 patients $(16 \%)$ and greater than 2500 patients (22\%). The majority of family physicians (75\%) spent between $76-100 \%$ of their time in clinical practice. All family physicians reported using a computer in their practice; $60 \%$ for billing, scheduling and registration; $30 \%$ for billing and only $10 \%$ reported that they kept full electronic records.

The level of agreement with statements about primary care reform is presented in Table 4 . A substantial majority (72\%) of physicians did not expect to join the Network by 2004 or by some later date after 2004 (60\%). If the intermediate category, 'slightly disagree' was included, these estimates rose to $84 \%$ and $76 \%$ respectively. The proportion of persons who reported that they never expected to join the network was $82 \%$. Thirty six percent of responders either agreed or strongly agreed with the statement that they did not understand the Network well enough to make an informed decision about it. Forty eight percent of responders agreed or strongly agreed that the current system for the organization of primary care delivery required change and many responders (60\%) agreed or strongly agreed with the statement that the financing of primary care requires change. Nevertheless, few responders agreed with the statement that capitation $(10 \%)$ or rostering (23\%) would improve primary care in Ontario. Many responding physicians $(68 \%)$ believed that appropriate incentives would enhance prevention. Thirty percent of responders agreed or strongly agreed that patients should always have access to extended office hours, while $42 \%$ agreed or strongly agreed that patients should have access to a telephone health line. Half the responders (51.9\%) agreed or strongly agreed that they would like to see computer systems replace papers systems in their practice.

Odds ratios and their associated 95\% confidence intervals are presented in Table 5. Younger physicians were less likely $(\mathrm{OR}=0.62)$ to agree that rostering would improve primary care and that patients should have access to extended hours $(\mathrm{OR}=0.49)$. Physicians in practice 9 years or less, were 1.6 times more likely to expect to join the Network by 2004, or after $2004(\mathrm{OR}=1.67)$. Solo practice physicians were less likely $(\mathrm{OR}=0.65)$ to agree with the idea of extended hours and of computers replacing paper systems $(\mathrm{OR}=0.41)$. Physicians in small practices were less likely (0.64) to understand the reforms and to favour telephone health lines $(\mathrm{OR}=0.65)$. They were 1.49 times more likely to report that they expected to join the Network after 2004. Those physicians remunerated on a feefor-service basis were less likely to agree with statements about joining by 2004 (OR =0.25), or after 2004 (OR = $0.47)$, that the organization required changing $(\mathrm{OR}=$ $0.29)$, favour capitation $(\mathrm{OR}=0.27)$, rostering $(\mathrm{OR}=$ $0.34)$, financial incentives for prevention $(\mathrm{OR}=0.41)$, or 
Table 4: Percent level of agreement with statements about primary care reform.

\begin{tabular}{|c|c|c|c|c|c|c|}
\hline Statement & $\begin{array}{l}\text { Strongly } \\
\text { agree }\end{array}$ & Agree & $\begin{array}{l}\text { Slightly } \\
\text { agree }\end{array}$ & $\begin{array}{l}\text { Slightly } \\
\text { disagree }\end{array}$ & Disagree & $\begin{array}{l}\text { Strongly } \\
\text { disagree }\end{array}$ \\
\hline & $\%$ & $\%$ & $\%$ & $\%$ & $\%$ & $\%$ \\
\hline $\begin{array}{l}\text { I understand the Ontario Family Health Network well } \\
\text { enough to make informed decisions about my } \\
\text { involvement }(n=574)\end{array}$ & 8.9 & 27.7 & 18.3 & 9.1 & 24.4 & 11.7 \\
\hline $\begin{array}{l}\text { I expect to be part of the Ontario Family Health } \\
\text { Network by } 2004(n=562)\end{array}$ & 3.1 & 4.3 & 8.7 & 12.1 & 33.3 & 38.6 \\
\hline $\begin{array}{l}\text { I expect to be part of the Ontario Family Health } \\
\text { Network at some time after } 2004(n=549)\end{array}$ & 1.8 & 5.8 & 16.4 & 16.4 & 27.7 & 31.9 \\
\hline $\begin{array}{l}\text { The current system for the organization of primary care } \\
\text { delivery in Ontario needs to be changed }(n=568)\end{array}$ & 14.4 & 33.1 & 26.8 & 7.8 & 12.7 & 5.3 \\
\hline $\begin{array}{l}\text { The current system for the financing of primary care } \\
\text { delivery in Ontario needs to be changed }(n=567)\end{array}$ & 25.2 & 34 & 19.6 & 6.2 & 10.2 & 4.8 \\
\hline $\begin{array}{l}\text { A capitation based formula for funding physician services } \\
\text { would improve primary care in Ontario }(n=556)\end{array}$ & 3.4 & 6.5 & 17.3 & 14.6 & 31.7 & 26.6 \\
\hline $\begin{array}{l}\text { A roster that links a patient to a single care provider } \\
\text { would improve primary care in Ontario }(n=564)\end{array}$ & 6 & 16.5 & 27.5 & 9.6 & 22.2 & 18.3 \\
\hline $\begin{array}{l}\text { Appropriate financial incentives would enhance } \\
\text { preventive interventions in primary care }(n=567)\end{array}$ & 23.5 & 44.4 & 19.6 & 3.4 & 6.4 & 2.8 \\
\hline $\begin{array}{l}\text { Patients should always have access to extended } \\
\text { weeknight and weekend office hours }(n=568)\end{array}$ & 4.4 & 25.9 & 22.2 & 13.2 & 24.5 & 9.9 \\
\hline $\begin{array}{l}\text { A telephone health line staffed by a qualified nurse is a } \\
\text { good resource to direct patients to appropriate care }(n= \\
569)\end{array}$ & 9 & 33.2 & 28.3 & 8.6 & 13.9 & 7 \\
\hline $\begin{array}{l}\text { I would like to see computer systems replace most of } \\
\text { the paper systems in my practice }(n=563)\end{array}$ & 22.6 & 29.3 & 20.4 & 8.5 & 13 & 6.2 \\
\hline
\end{tabular}

extended access for patients $(\mathrm{OR}=0.58)$. Those who derived less than $75 \%$ of their income from clinical practice, were less likely to understand the reforms (0.65), much more likely to agree that the financing of primary care required changing ( $\mathrm{OR}=2.38)$, agree with both capitation $(\mathrm{OR}=1.83)$ and rostering $(\mathrm{OR}=1.77)$, and favour extended access for patients $(\mathrm{OR}=1.58)$.

Three possible explanations for a physicians intention to join the Network were assessed. Neither a lack of understanding of the reform initiative $(\mathrm{OR}=1.5,95 \%$ C.I.s $0.96-2.3)$, nor the possibility that physicians were already practising in a manner similar to that proposed by the Network, were statistically significant explanations for the stated intention to join the Network (OR $=1.3,95 \%$ C.I.s 0.6-2.9). The main factor associated with a physicians intent to join by 2004 was related to method of payment - physicians who favour capitation were 5.5 times more likely to report that they expected to join the Network by 2004 (O.R. $=5.5,95 \%$ C.I.s 3.5-8.7).

\section{Discussion}

This study has described the views of physicians about primary care reform in Ontario. While many physicians recognize the need for change in both the organization and financing of primary care, the majority of physicians do not expect to join the Network, and half of them do not understand the Network enough to make an informed decision about participating. Physicians are divided on issues such as patient rostering and extended hours, although many support the idea of financial incentives for preventive interventions or a telephone health line. Whether or not a physician was remunerated on a fee-forservice basis strongly influenced their views on reform. Physicians on fee-for-service were less likely to: report that they would join the Network; believe that the organization of primary care required changing; support rostering or capitation; favour financial incentives for prevention; or support extended access for patients. Physicians who spent less than $75 \%$ of their work in clinical practice were more likely to agree that the financing of primary care required changing, and to favour both capitation, rostering and extended access for patients. Physicians who favour capitation were 5.5 times more likely to report that they intended to join the Network by 2004. Although many responders did not understand the Network, the only statistically significant explanation was that physicians did not support capitation. 
Table 5: Statistically significant relationship between characteristic of family physicians and their level of agreement with statements about primary care reform, odds ratios with their $95 \%$ confidence intervals.

\begin{tabular}{|c|c|c|c|c|c|c|}
\hline & Age group & $\begin{array}{l}\text { Years in } \\
\text { practice }\end{array}$ & Practice type & $\begin{array}{l}\text { Size of } \\
\text { practice }\end{array}$ & $\begin{array}{l}\text { Primary } \\
\text { clinical } \\
\text { Incomee }\end{array}$ & $\begin{array}{l}\text { Percenttime } \\
\text { in clinical } \\
\text { practice }\end{array}$ \\
\hline & $\begin{array}{l}<44 \text { vs. } 45+ \\
\text { years }\end{array}$ & $\begin{array}{l}0-9 \text { vs. } 10+ \\
\text { years }\end{array}$ & $\begin{array}{l}\text { Solo vs. all } \\
\text { others * }\end{array}$ & $\begin{array}{l}<1500 \text { vs. } \\
1500+ \\
\text { patients }\end{array}$ & $\begin{array}{l}\text { Fee-for- } \\
\text { service vs. all } \\
\text { others** }\end{array}$ & $<75 \%$ vs. $75 \%+$ \\
\hline $\begin{array}{l}\text { Understand the network } \\
\text { enough to make informed } \\
\text { decision about involvment }\end{array}$ & & & & $0.64(0.46-0.90)$ & & $0.65(0.45-0.95)$ \\
\hline $\begin{array}{l}\text { Expect to be part of network } \\
\text { by } 2004\end{array}$ & & $1.60(1.03-2.50)$ & & & $0.25(0.16-0.40)$ & \\
\hline $\begin{array}{l}\text { Expect to be part of network } \\
\text { afer } 2004\end{array}$ & & $1.67(1.14-2.45)$ & & $1.49(1.03-2.16)$ & $0.47(0.31-0.73)$ & \\
\hline $\begin{array}{l}\text { Oorganization of primary } \\
\text { care needs changing }\end{array}$ & & & & & $0.29(0.15-0.55)$ & \\
\hline $\begin{array}{l}\text { Financing primary care needs } \\
\text { changing }\end{array}$ & & & & & & $2.38(1.37-4.14)$ \\
\hline $\begin{array}{l}\text { Capitation would improve } \\
\text { primary care }\end{array}$ & & & & & $0.27(0.17-0.4 I)$ & $1.83(1.24-2.72)$ \\
\hline $\begin{array}{l}\text { Rostering would improve } \\
\text { primary care }\end{array}$ & $0.62(0.45-0.87)$ & & & & $0.34(0.27-0.53)$ & $1.77(1.21-2.56)$ \\
\hline $\begin{array}{l}\text { Financial incentives would } \\
\text { preventive care }\end{array}$ & & & & & $0.41(0.18-0.93)$ & \\
\hline $\begin{array}{l}\text { Patients should have } \\
\text { weeknight and weekend } \\
\text { access }\end{array}$ & $0.49(0.35-0.69)$ & & $0.65(0.45-0.93)$ & & $0.58(0.38-0.89)$ & $1.58(1.08-2.33)$ \\
\hline $\begin{array}{l}\text { Telephone health line is a } \\
\text { good resource }\end{array}$ & & & & $0.65(0.45-0.95)$ & & \\
\hline $\begin{array}{l}\text { Favours computer systems } \\
\text { to replace paper }\end{array}$ & & & $0.4 \mathrm{I}(0.28-0.6 \mathrm{I})$ & & & \\
\hline
\end{tabular}

* All other type of practices includes: group, community health centre, health services organization and other. ** All other type of primary income includes:capitation, salary and other.

The limitations of this study ought to be considered before any conclusions be drawn. These results may be limited by the representativeness of the sample and by the reliability and validity of the questions used to determine views about reform. The representativeness of this sample is influenced by sampling bias and response bias. Our survey was based on a $20 \%$ random sample of the Ontario College of Family Physicians, that represents $65 \%$ of practicing family physicians in Ontario. This sampling frame excluded general practitioners who are not certified in Family Medicine, but who are eligible to participate in the reforms. These physicians are likely to be older than certified family physicians and may hold different views from those sampled in this study. The extent that this exclusion may bias these results is unknown, although that it may be minimal is suggested by the finding that non-certified general practitioners were equally likely to join a pilot primary care reform site as those who were members of the Ontario College of Family Physicians [10]. Responders in our survey were more likely to be younger, to be women and to have practised for less time, than physicians who responded (53\%) to the Ontario portion of the National Family Physician Workforce Survey. While, we acknowledge the possibility of sampling bias, we feel that the views of younger physicians may be more relevant because they are more likely to be the ones who are targets of the reform initiative. The low response rate (50\%) was expected as it is well known that busy clinicians frequently do not complete questionnaires. Nevertheless, our response rate is comparable to that of the National Family Physician Workforce survey (53\%) and a recently published survey of Ontario family physicians $(47 \%)[11,13]$.

Second, the way that the questions were phrased could bias the results. The questions used to determine the views of physicians were developed by the authors for this study and were not tested for their reliability and validity. Nevertheless, the questions were developed by the authors, whose expertise ranged from questionnaire design (DH), to primary care research (MG) and family medicine (SS, $M G$ ) and reflect the stated objectives of the Ontario initiative. We believe they had face validity. Interpretation of 
these results was based on the extent that responders agreed or strongly agreed with the statements. Depending on whether the "slightly agreed" category was included, interpretation of the results may differ - for example the majority agree with all but three statements (those about whether physicians expected to join the network and about capitation). A third limitation is that the survey was conducted a few months after the initiative was launched. The diffusion of innovations tends to have an initial latent phase before rapidly accelerating adoption. While it is possible that our survey only reflects this latency period, the fact that more than a year after the Network launch, only $5 \%$ of eligible physicians have joined, suggests that we have captured long-term intentions.

What are the implications of these findings for reform initiatives in Ontario? The majority of family physicians reported that they were unlikely to participate in the Network because they were opposed to capitation and patient rosters. In a study of the pilot phase of Ontario primary care reform physicians in Ontario's capitated Health Service Organizations were no more likely to join than fee-for-service physicians[10]. In contrast, we found that a physicians support for capitation was associated with their intent to join the Network. Capitation payment is a key element in primary care restructuring not only in Canada but also in many foreign jurisdictions[14]. It was the funding method officially endorsed by the Health Services Restructuring Commission in 1999 and is the dominant element in the Network remuneration scheme[15]. Nevertheless, in Ontario almost 95\% of physicians are currently paid by fee-for-service[1]. For them, capitation may be associated with the unpopular principle in Ontario's Health Service Organizations where payment for patients attending a source of primary care outside the practice is withheld for that month. It has also been suggested that capitation may lead to loss of autonomy [16]. Finally, it may be that Ontario family physicians disapprove of capitated practice because they just don't like change, a view supported by their reaction to many elements in contemporary health reform [9]. Opposition to capitation is not confined to Ontario practitioners. In the USA, physicians who were introduced to partial capitation funding had strong negative views of the method and, while these views tended to moderate with time, capitation continued to be rated far below fee-for-service $[17,18]$.

Currently the vast majority of family physicians operate on a fee-for-service basis, with a significant number in solo practice. The decision not to be part of the network does not mean the physician will not be providing service. This may inhibit the incorporation of innovations, such as nurse practitioners or the electronic medical record, into existing practices with attendant implications for health human resources and quality of care respectively. Moreo- ver, existing models of practice lack the capacity to address distributional issues. If all citizens were rostered to specific practices, there would be competition for patients. Some physicians now located in the urban south might be forced under such a capitated payment scheme to migrate to less serviced areas in order to acquire an adequate list of patients.

Many physicians reported that they did not fully understand the Network and may be unaware that it allows for a blended payment scheme including both capitation and fee-for-service. Since physicians may equate primary care reform largely with a switch to capitated payment, the successful recruitment to the Network will require the education of physicians about payment. Borrowing from strategy used to introduce Health Services Organizations, government suggested a process to compare the fee-forservice billings of potential recruits with their possible earnings under Network rules $[1,16]$. Additionally, they need to emphasize that a selection of retained fee-for-service billing codes and the system of target achievement bonuses brings the Network's payment formula closer to a blended scheme favoured by many physicians $[1,19]$. The key message, however, is that experience from many countries confirms that primary care reform does not succeed without the active support of the physicians involved [14]. The alternative is to see the Network fail to attract widespread participation, as did its Health Services Organization and Community Health Centre predecessors $[16,20]$. Since the launch of the Ontario Family Health Network, government has introduced a variant of fee-for-services with a number of incentives, known as family health groups that are proving more popular than the family health networks.

\section{Conclusions}

The results of this survey, conducted five months after the initial offering of primary care reform agreements to all Ontario physicians, suggest that a $80 \%$ enrolment target is unrealistic.

\section{Competing interests}

None declared.

\section{Authors' contributions}

DH was the principal investigator of the study and takes responsibility for the integrity of the work as a whole. SEDS, PW, and MG made substantial contributions to the conception and design of the study, to the acquisition of data, and to the analysis and interpretation of data. All authors critically reviewed drafts of the manuscript and have approved the final version.

\section{References}

I. Hutchison B, Abelson J, Lavis J: Primary care in Canada: So much innovation, so little change. Health Aff 200I, 20:I I6-I3I. 
2. World Health Organization: Primary health care: $\mathbf{A}$ framework for future strategic directions. Geneva 2003.

3. Commission on Medicare: Caring for medicare: Sustaining a quality system. Regina $200 \mathrm{I}$.

4. Premier's Advisory Council on Health: A framework for reform. Edmonton 200I.

5. Standing Senate Committee on Social Affairs, Science and Technology: The health of Canadians the federal role. Issues and options. Ottawa 200I, 4:

6. Commission on the Future of Health Care in Canada: Shape the future of health care. Ottawa 2002.

7. PricewaterhouseCoopers: Ontario Ministry of Health and LongTerm Care: Evaluation of Primary Care Reform Pilots in Ontario; Phase 2 Interim Report. Toronto 200I.

8. PricewaterhouseCoopers: Ontario Ministry of Health and LongTerm Care: Evaluation of Primary Care Reform Pilots in Ontario; Phase I Final Report. Toronto 200I.

9. Cohen M, Ferrier B, Woodward CA, Brown J: Health care system reform, Ontario family physicians' reactions. Can Fam Physician 200I, 47:I777-I 784 .

10. Neimanis IM, Paterson JM, Allega RL: Primary care reform: Physicians' participation in Hamilton-Wentworth. Can Fam Physician 2002, 48:306-313.

II. The JANUS Project, College of Family Physicians of Canada: The 2001 CFPC National Family Physician Workforce Survey Database. Mississauga 200I.

12. SAS Institute Inc: Proprietary Software Release 8.2 (TS2M0). Cary . 1999-200I

13. Delva MD, Kirby JR, Knapper CK, Birtwhistle RV: Postal survey of approaches to learning among Ontario physicians: implications for continuing medical education. $B M]$ 2002, 325: 1218 .

14. Mable AL, Marriott J: Opportunities and potential: A review of international literature on primary health care reform and models. Ottawa: Health Canada 2000.

15. Health Services Restructuring Commission: Primary health care strategy. Advice and recommendations to the honourable Elizabeth Witmer, Minister ofHealth. Toronto 1999.

16. Gillett J, Hutchison B, Birch S: Capitation and primary care in Canada: financial incentives and the evolution of health service organizations. Int J Health Serv 200 I, 3 I:583-603.

17. Tyrance PH Jr, Sims S, Ma'luf N, Fairchild D, Bates DW: Capitation and its effects on physician satisfaction. Cost Qual $Q J 1999$, 5:12-18.

18. Nadler ES, Sims S, Tyrance PH Jr, Fairchild DG, Brennan TA, Bates DW: Does a year make a difference? Changes in physician satisfaction and perception in an increasingly capitated environment. Am J Med 1999, 107:38-44.

19. Rosser WW, Kasperski J: Argument for blended funding. Can Fam Physician 2002, 48:236-237.

20. Suschnigg C: Reforming Ontario's primary health care system: one step forward, two steps back? Int J Health Serv 200I, 31:91-103.

\section{Pre-publication history}

The pre-publication history for this paper can be accessed here:

http://www.biomedcentral.com/1471-2296/5/2/prepub
Publish with Biomed Central and every scientist can read your work free of charge

"BioMed Central will be the most significant development for disseminating the results of biomedical research in our lifetime. "

Sir Paul Nurse, Cancer Research UK

Your research papers will be:

- available free of charge to the entire biomedical community

- peer reviewed and published immediately upon acceptance

- cited in PubMed and archived on PubMed Central

- yours - you keep the copyright
BioMedcentral 